\title{
Development and Standardization of Ripe Pumpkin Based Squash and its Stability during Storage
}

\author{
Anju K. Dhiman, G. Nagendra Babu, Attri Surekha and Ramchandran Preethi*
}
Department of Food Science and Technology, College of Horticulture, Dr Y S Parmar University of Horticulture and Forestry, Nauni, Solan (HP)-173230, India
*Corresponding author

\section{Ke y w o r d s \\ Ripe pumpkin, Guava, Squash, $\beta$-carotene, Ascorbic acid and overall acceptability.}

\section{Article Info}

Accepted:

04 September 2017

Available Online:

10 October 2017

\section{A B S T R A C T}

The present investigation was carried out in the Department of Food Science and Technology, Dr Y S Parmar University of Horticulture and Forestry, Nauni, Solan (HP). Squash was prepared using different proportion of pumpkin pulp $(25,30,35,40$ and 45 per cent) and total soluble solids $\left(40,45\right.$ and $47^{\circ}$ Brix) to finalise the base recipe. The squash was liked by the panellists but the feedback of judges revealed that the flavour of the product is required to be improved. Keeping in view the remarks of panellists, the squash was prepared by blending the pumpkin pulp with different proportion of guava pulp. Among different recipes tried for development and standardization of pumpkin-guava squash, recipe $\mathrm{PG}_{2}$ (30\% pumpkin pulp+10\% guava pulp) was selected for further studies on the basis of sensory evaluation in which acidity was maintained with three different acidic medium. Among, different squash prepared with three different acidic medium, the maximum ascorbic acid was noticed in treatment T2 $(58.07 \mathrm{mg} / 100 \mathrm{~g})$ while the beta carotene was maximum in $\mathrm{T} 1$ and $\mathrm{T} 2(0.51 \mathrm{mg} / 100 \mathrm{~g})$. It was noticed that with the increase in storage period there was changes in chemical and organoleptic properties of prepared squash. The properties such as TSS, total sugars and reducing sugars increased however, titrable acidity, ascorbic acid and beta carotene decreased. At the end of six month of storage, it was observed that the mean maximum value of ascorbic acid decreased from 51.59 to $45.79 \mathrm{mg} / 100 \mathrm{~g}$ while the beta carotene decreased from 0.51 to $0.22 \mathrm{mg} / 100 \mathrm{~g}$. Similarly, there were changes in the organoleptic properties of pumpkin guava based squash after six month of storage, but all of them were above the acceptable limit. The overall acceptability scores decreased from 8.13 to 6.68 . Hence, it can be said that pumpkin along with guava can be effectively utilized for the development of squash which can be a good source of ascorbic acid.

\section{Introduction}

Pumpkin which is commonly known as 'kashiphal' or 'lal kaddhu' belongs to the family Cucurbitaceae and the genus Cucurbita. It is an annual or perennial, climbing or trailing herb indigenous to arid and temperate regions (Kulkarni and Joshi, 2013). It is a vegetable coming from tropical and subtropical zones such as Mexico and South America with high consumption in the local market (Bisognin, 2002). The name pumpkin originated from a Greek word Pepon which means large melon. Pumpkin is composed of Cucurbita mos chata, Cucurbita pepo, Cucurbita maxima, Cucurbita mixta, 
Cucurbita facifola and Telfairia occidental (Caili et al., 2006). Cucurbita moschata is grown in almost all the regions of India while C. maximum are mostly grown in the hills and subtropical regions. The fruits of pumpkin are variable in size, shape (round or oval) and colour (Pandey et al., 2003). Pumpkin is rich source of biologically active compounds and is recommended for diseases such as arthrosclerosis and helps to reduce the cholesterol in people suffering from diabetes (Danilchenko et al., 2000). Pumpkin has vast scope of diversification for its application in commercial production of value added products such as jam, jelly, marmalades, puree, sauces, chutney, pickle, cookies, weaning mix (Dhiman et al., 2009), Instant halwa mix (Dhiman et al., 2017), pies and beverages.

A beverage is an important culinary preparation and is a drink specifically prepared for human consumption and contributes greatly to quench the thirst. The beverages are marketed under a variety of names such as fruit drink, breakfast drink. Ready-to-serve (RTS), nectar, squash, spices squash etc. (Kumar et al., 2013). A fruit squash consist of juice containing moderate quantity of fruit pulp to which cane sugar is added for sweetening. Minimum percentage of fruit juice content and TSS in the final product $(\mathrm{w} / \mathrm{w})$ shall not be less than 25 per cent and $40^{\circ} \mathrm{B}$, respectively. The increasing popularity of beverages in the country due to its health and nutritional benefits apart from providing pleasant taste and flavour has increased the consumption of beverage from 30 to 80 per cent in last three years.

India with its varied agro climate base is uniquely placed for growing a large number of horticulture crops for possible value addition as beverages. Today market is flooded with a large variety of beverages yet the researches and food processers are looking for new raw material of high nutritional value to be used for the production of beverages. A substantial amount of research work both at national as well as international level is going on in studying and developing a variety of beverages from fruits and vegetables which are locally available in abundance and which perish in large quantities due to lack of appropriate convert options and/or techniques. Therefore, there is an opportune moment to promote the use of pumpkin in development of beverages which shall go a long way in not only meeting the nutritional requirements of the population but will have positive impact on the national economy and substantial rural development.

\section{Materials and Methods}

The present investigations were conducted in the Department of Food Science and Technology, Dr YS Parmar University of Horticulture and Forestry, Nauni, Solan (HP) during the year 2013-2015. Raw material such as pumpkin, lime and hill lemon used for conducting the study were procured from Subzi Mandi/local market of Solan. Sugar was brought from local vendor of Nauni, while the chemical used in the study was purchased from International Scientific and Surgicals, Solan (HP).

\section{Preparation of ripe pumpkin pulp}

Ripe pumpkins were thoroughly washed and cut into halves. After removing the seeds and fluffy portion (fibrous strains/brains), pumpkins were cut into slices. The slices were peeled, washed and further cut into small pieces. The pumpkin pieces were pressure cooked with 10 per cent water for 5 min. The whole mass was then converted in to pulp by grinding in mixer cum grinder (Model MX-1155) and was strained to remove any of the fibre present in the pulp. 
Development and standardization of recipe for preparation of pumpkin squash

FSSAI specifications were followed for preparation of squash from ripe pumpkin pulp. Different combinations of pumpkin pulp $(\%)$ and TSS $\left({ }^{\circ} \mathrm{B}\right)$ were used to prepare squash (Table 1). The concentration of acid (as citric acid) was kept constant $(1.2 \%)$ in all the combinations. Potassium metabisulphite (KMS) @ 350 ppm was mixed properly at the end of product preparation. The squash was filled in previously sterilized glass bottles leaving adequate head space $(1.2 \mathrm{~cm})$ and sealed. Pumpkin squash of different combinations after dilution (1:3) was subjected to sensory evaluation by a panel of ten judges. The combination which received the highest overall acceptability score was selected as base recipe for further studies.

As per the feedback from panellists regarding improvement in flavour of squash, the pumpkin pulp was blended with guava pulp. The fruits were washed, cut into small pieces. Fruit pieces were mixed with equal amount of water (1:1) followed by pressure cooking for 15 minutes. The whole mass was converted in to pulp by grinding in a mixer cum grinder. The obtained pulp was strained through strainer to get fine pulp. The pulp was then used to prepare pumpkin squash blended with guava pulp.

Three different lots of squash were prepared by using the recipe which received the maximum sensory scores by the panellists. The acidity of squash was adjusted by using different acidic medium viz. citric acid, lime juice and hill lemon juice and was referred as $\mathrm{T}_{1}, \mathrm{~T}_{2}$ and $\mathrm{T}_{3}$, respectively (Table 3 ).

\section{Method of analysis}

Total soluble solids was measured by using ERMA company made hand refractometer at ambient temperature whereas, the acidity was determined by titrating known quantity of sample against $0.1 \mathrm{~N}$ sodium hydroxide solution using phenolphthalein as an indicator and expressed in per cent anhydrous citric acid (AOAC, 2012). The reducing and total sugars were analysed by using Fehling's solution $\mathrm{A}$ and $\mathrm{B}$ and methylene blue as an indicator (AOA, 2012). Vitamin C content was estimated by preparing sample in 3 per cent metaphosphoric acid solution and titrating against 2, 6 dichlorophenol indophenols dye solution till the appearance of light pink colour (Ranganna, 2009). The $\beta$ carotene was estimated as per the procedures outlined by Ranganna (2009). A panel of 10 semi trained judges evaluated RTS for its colour, body, taste, aroma and overall acceptability on 9-point Hedonic scale. The data for quantitative analysis of various physic-chemical attributes were analysed by Completely Randomized Design (CRD) while the data on sensory evaluation were analysed by Randomized block design (RBD).

\section{Results and Discussion}

\section{Standardization of recipe for preparation of pumpkin squash}

The recipes of different treatments were subjected to sensory evaluation and the results (Figure 1) indicated that treatment $\mathrm{S}_{9}(40 \%$ pulp and $45^{\circ} \mathrm{B}$ TSS) was awarded the highest scores for all the sensory characteristics. Therefore, this treatment was selected for further studies. Though the squash was liked by the panellists but the feedback of judges revealed that the flavour of the product is required to be improved. Keeping in view the remarks of panellists, the squash was prepared by blending the pumpkin pulp with different proportions of guava pulp which has a strong flavour and the different combinations of pumpkin-guava squash were subjected to sensory evaluation by a panel of ten judges. The data (Figure 2) showed that significantly higher score for colour (8.30), body (8.07), 
taste (7.27), aroma (8.23) and overall acceptability (8.33) was awarded to $\mathrm{PG}_{2}$ (30 $\%$ pumpkin pulp+10 \% guava pulp). However, the scores for various sensory attributes were well above the acceptable limits of all the recipes but the recipe $\mathrm{PG}_{2}$ which got the highest overall acceptability score was selected for further studies. The selected recipe was taken as base for preparation of pumpkin-guava squash by maintaining the acidity with three different acidic medium i.e. citric acid, lime and hill lemon juice and referred, respectively as $\mathrm{T}_{1}$, $\mathrm{T}_{2}$ and $\mathrm{T}_{3}$.

\section{Changes in chemical characteristics of pumpkin-guava squash during storage}

\section{Total soluble solids (TSS)}

The data pertaining to the effect of different treatments on TSS of pumpkin-guava squash during storage is given in Table 4. It is clear from the data that among different treatments mean maximum $\left(45.45^{\circ} \mathrm{B}\right)$ value was recorded in $\mathrm{T}_{1}$ (pumpkin-guava pulp + citric acid) and mean minimum $\left(45.25^{\circ} \mathrm{B}\right)$ in $\mathrm{T}_{3}$ (pumpkin-guava pulp+hill lemon juice). During storage of six months, the mean value was observed to increase from 45.00 to 45.58 ${ }^{0} \mathrm{~B}$. Increase in TSS might be due to the hydrolysis of polysaccharides like pectin, starch etc. into simple sugars. The results are in conformity with the findings of Palinswamy et al., (1984) in mango squash, Kannan and Tirumanan (2002) in jamun squash, Ali et al., (2011) in seabuckthorn squash, Diwedi and Pathak (2012) in mulberry squash, Kayshar et al., (2014) in mixed fruit squash and Shahid et al., (2015) in mango-mandarin squash.

\section{Titrable acidity}

Changes in titrable acidity of pumpkin-guava squash during storage revealed a significant decreasing trend (Table 4). The mean maximum value of 1.14 per cent was recorded in $\mathrm{T}_{1}$ (pumpkin-guava pulp + citric acid) while mean minimum of 1.02 per cent in $\mathrm{T}_{3}$ (pumpkin-guava pulp + hill lemon juice). During storage, titrable acidity of pumpkinguava squash was found to decrease from 1.20 to 0.98 per cent. The decrease in titrable acidity during storage might be due to copolymerization of organic acids with sugars and amino acids or due to the chemical interaction between the organic constituents affected by the temperature and action of enzymes (Malav et al., 2014). Similar trend has also been reported by Kannan and Thirumran (2004) in jamun squash, Hussain et al., (2005) in mango squash, Reddy and Chikkasubbanna (2008) in lime blended amla squash and Syed et al., (2012) in sweet orange squash.

\section{Total sugars}

There was a significant increase in total sugars of pumpkin-guava squash during six months of storage period under ambient condition (Table 5). The highest mean value (41.47\%) for total sugars was recorded in $T_{1}$ (pumpkin-guava pulp + citric acid) and the lowest $(39.37 \%)$ in $\mathrm{T}_{3}$ (pumpkin-guava pulp + hill lemon juice). During storage of six months, the mean value for total sugars was found to increase significantly from 39.05 to 42.17 per cent. The increase in total sugars might be due to hydrolysis of starch into sugars as well as conversion of complex polysaccharides into simple sugars. Similar increase in sugars during storage has been reported by Prasad and Mali (2000) in pomegranate squash, Ali et al., (2011) in seabuckthorn squash, Relekar et al., (2013) in sapota squash and Sharma et al., (2009) in guava-jamun squash.

\section{Reducing sugars}

The data collected on the effect of different treatments and storage intervals on reducing 
sugars of pumpkin-guava squash are appended in Table 5. The mean maximum $(22.48 \%)$ and mean minimum $(17.84 \%)$ reducing sugars were recorded, respectively in $\mathrm{T}_{1}$ (pumpkin-guava pulp+citric acid) and $\mathrm{T}_{3}$ (pumpkin-guava pulp+hill lemon juice). The reducing sugars of pumpkin-guava squash increased from 17.52 to 21.97 per cent during the entire storage period of six months.

Table.1 Treatment detail of pumpkin squash

\begin{tabular}{|c|c|c|}
\hline Treatment (S) & Pumpkin pulp (\%) & TSS $\left({ }^{\mathbf{}} \mathbf{B}\right)$ \\
\hline $\mathbf{S}_{\mathbf{1}}$ & 25 & 40 \\
\hline $\mathbf{S}_{\mathbf{2}}$ & 30 & 40 \\
\hline $\mathbf{S}_{\mathbf{3}}$ & 35 & 40 \\
\hline $\mathbf{S}_{\mathbf{4}}$ & 40 & 40 \\
\hline $\mathbf{S}_{\mathbf{5}}$ & 45 & 40 \\
\hline $\mathbf{S}_{\mathbf{6}}$ & 25 & 45 \\
\hline $\mathbf{S}_{\mathbf{7}}$ & 30 & 45 \\
\hline $\mathbf{S}_{\mathbf{8}}$ & 35 & 45 \\
\hline $\mathbf{S}_{\mathbf{9}}$ & 40 & 45 \\
\hline $\mathbf{S}_{\mathbf{1 0}}$ & 45 & 45 \\
\hline $\mathbf{S}_{\mathbf{1 1}}$ & 25 & 47 \\
\hline $\mathbf{S}_{\mathbf{1 2}}$ & 30 & 47 \\
\hline $\mathbf{S}_{\mathbf{1 3}}$ & 35 & 47 \\
\hline $\mathbf{S}_{\mathbf{1 4}}$ & 40 & 47 \\
\hline $\mathbf{S}_{\mathbf{1 5}}$ & 45 & 47 \\
\hline
\end{tabular}

Table.2 Optimization of pumpkin and guava pulp ratio for preparation of squash

\begin{tabular}{|c|c|c|}
\hline Treatment (PG) & Pumpkin pulp (\%) & Guava pulp (\%) \\
\hline $\mathrm{PG}_{1}$ & 25 & 15 \\
\hline $\mathrm{PG}_{2}$ & 30 & 10 \\
\hline $\mathrm{PG}_{3}$ & 35 & 5 \\
\hline $\mathrm{PG}_{4}$ & 40 & 0 \\
\hline
\end{tabular}

Table.3 Treatment detail of pumpkin-guava squash

\begin{tabular}{|c|l|c|}
\hline Treatment (T) & Ingredients & Acidic medium \\
\hline $\mathbf{T}_{\mathbf{1}}$ & Pulp (pumpkin+guava) + sugar syrup & Citric acid \\
\hline $\mathbf{T}_{\mathbf{2}}$ & Pulp (pumpkin+guava) + sugar syrup & Lime juice \\
\hline $\mathbf{T}_{\mathbf{3}}$ & Pulp (pumpkin+guava) + sugar syrup & Hill lemon juice \\
\hline
\end{tabular}


Table.4 Effect of different treatments and storage on total soluble solids $\left({ }^{\circ} \mathrm{B}\right)$ and titrable acidity (\%) of pumpkin-guava squash

\begin{tabular}{|c|c|c|c|c|c|c|c|c|}
\hline & \multicolumn{3}{|c|}{ Total soluble solids $\left({ }^{\circ} \mathbf{B}\right)$} & & \multicolumn{4}{|c|}{ Titrable acidity (\%) } \\
\hline \multirow[t]{2}{*}{ Treatment $(\mathrm{T})$} & \multicolumn{3}{|c|}{ Storage interval (S) (months) } & & \multicolumn{4}{|c|}{ Storage interval (S) (months) } \\
\hline & 0 & 3 & 6 & Mean & 0 & 3 & 6 & Mean \\
\hline $\mathbf{T}_{1}$ & 45.00 & 45.62 & 45.73 & $\mathbf{4 5 . 4 5}$ & 1.20 & 1.14 & 1.07 & 1.14 \\
\hline $\mathbf{T}_{2}$ & 45.00 & 45.37 & 45.48 & 45.29 & 1.20 & 1.08 & 1.03 & $\mathbf{1 . 1 0}$ \\
\hline $\mathbf{T}_{3}$ & 45.00 & 45.22 & 45.51 & 45.25 & 1.20 & 1.01 & 0.85 & 1.02 \\
\hline Mean & 45.00 & 45.40 & 45.58 & & 1.20 & 1.08 & 0.98 & \\
\hline $\mathrm{CD}_{0.05}$ & \multicolumn{3}{|c|}{$\begin{array}{l}\mathrm{T}(\text { Treatments })=0.04 \\
\mathrm{~S}(\text { Storage interval })=0.04 \\
\mathrm{TXS}=0.06\end{array}$} & & \multicolumn{3}{|c|}{$\begin{array}{l}\mathrm{T}(\text { Treatments })=0.05 \\
\mathrm{~S}(\text { Storage interval }) 0.05 \\
\mathrm{TxS}=0.08\end{array}$} & \\
\hline
\end{tabular}

Table.5 Effect of different treatments and storage on total and reducing sugars (\%) of pumpkinguava squash

\begin{tabular}{|c|c|c|c|c|c|c|c|c|}
\hline \multirow{3}{*}{$\begin{array}{l}\text { Treatment } \\
\text { (T) }\end{array}$} & \multicolumn{3}{|c|}{ Total sugars (\%) } & \multirow[b]{3}{*}{ Mean } & \multicolumn{4}{|c|}{ Reducing sugars (\%) } \\
\hline & \multicolumn{3}{|c|}{$\begin{array}{lll}\begin{array}{l}\text { Storage } \\
(\text { months) }\end{array} & \text { interval } & \text { (S) }\end{array}$} & & \multicolumn{4}{|c|}{$\begin{array}{l}\text { Storage interval }(\mathbf{S}) \\
\text { (months) }\end{array}$} \\
\hline & 0 & 3 & 6 & & 0 & 3 & 6 & Mean \\
\hline $\mathbf{T}_{1}$ & 40.99 & 41.62 & 41.80 & 41.47 & 20.03 & 22.65 & 24.76 & 22.48 \\
\hline $\mathbf{T}_{2}$ & 38.50 & 39.68 & 42.04 & 40.08 & 16.66 & 18.89 & 21.13 & 18.90 \\
\hline $\mathbf{T}_{\mathbf{3}}$ & 37.67 & 39.99 & 40.45 & 39.37 & 15.88 & 17.62 & 20.03 & 17.84 \\
\hline Mean & 39.05 & 41.10 & 42.17 & & 17.52 & 19.72 & 21.97 & \\
\hline $\mathrm{CD}_{0.05}$ & \multicolumn{3}{|c|}{$\begin{array}{l}\mathrm{T}(\text { Treatments })=0.05 \\
\mathrm{~S}(\text { Storage interval })=0.05 \\
\mathrm{TxS}=0.08\end{array}$} & $\mathrm{CD}_{0.05}$ & \multicolumn{3}{|c|}{$\begin{array}{l}\mathrm{T}(\text { Treatments })=0.03 \\
\mathrm{~S}(\text { Storage interval })=0.03 \\
\mathrm{TxS}=0.06\end{array}$} & \\
\hline
\end{tabular}

Table.6 Effect of different treatments and storage on ascorbic acid $(\mathrm{mg} / 100 \mathrm{~g})$ and $\beta$ - carotene (mg/100 g) of pumpkin-guava squash

\begin{tabular}{|c|c|c|c|c|c|c|c|c|}
\hline \multirow{3}{*}{$\begin{array}{l}\text { Treatment } \\
\text { (T) }\end{array}$} & \multicolumn{3}{|c|}{ Ascorbic acid (mg/100 g) } & & \multicolumn{4}{|c|}{$\beta$ - carotene $(\mathrm{mg} / 100 \mathrm{~g})$} \\
\hline & \multicolumn{3}{|c|}{$\begin{array}{lll}\begin{array}{l}\text { Storage } \\
\text { (months) }\end{array} & \text { interval } & \text { (S) }\end{array}$} & & \multicolumn{4}{|c|}{$\begin{array}{l}\text { Storage interval }(\mathrm{S}) \\
\text { (months) }\end{array}$} \\
\hline & 0 & 3 & 6 & Mean & 0 & 3 & 6 & Mean \\
\hline $\mathbf{T}_{1}$ & 43.02 & 37.82 & 35.75 & 38.86 & 0.51 & 0.46 & 0.32 & $\mathbf{0 . 4 3}$ \\
\hline $\mathbf{T}_{2}$ & 58.07 & 56.29 & 53.38 & 55.91 & 0.51 & 0.42 & 0.23 & 0.38 \\
\hline $\mathbf{T}_{3}$ & 53.67 & 50.07 & 48.25 & 50.66 & 0.50 & 0.38 & 0.12 & 0.33 \\
\hline Mean & 51.59 & 48.06 & 45.79 & & 0.51 & 0.42 & 0.22 & \\
\hline $\mathrm{CD}_{0.05}$ & \multicolumn{3}{|c|}{$\begin{array}{l}\mathrm{T}(\text { Treatments })=0.04 \\
\mathrm{~S}(\text { Storage interval })=0.04 \\
\mathrm{TxS}=0.07\end{array}$} & $\mathrm{CD}_{0.05}$ & \multicolumn{3}{|c|}{$\begin{array}{l}\mathrm{T}(\text { Treatments })=0.05 \\
\mathrm{~S}(\text { Storage interval })=0.05 \\
\mathrm{TxS}=0.08\end{array}$} & \\
\hline
\end{tabular}


Table.7 Effect of different treatments and storage on colour and body scores of pumpkin-guava squash (on 9 point hedonic scale)

\begin{tabular}{|c|c|c|c|c|c|c|c|c|}
\hline \multirow[t]{3}{*}{ Treatment (T) } & \multicolumn{3}{|c|}{ Colour } & & \multicolumn{4}{|c|}{ Body } \\
\hline & \multicolumn{3}{|c|}{$\begin{array}{l}\text { Storage interval } \\
\text { (months) }\end{array}$} & \multirow[b]{2}{*}{ Mean } & \multicolumn{4}{|c|}{$\begin{array}{l}\text { Storage interval }(S) \\
\text { (months) }\end{array}$} \\
\hline & 0 & 3 & 6 & & 0 & 3 & 6 & Mean \\
\hline $\mathbf{T}_{1}$ & 8.30 & 8.07 & 7.40 & 7.92 & 8.07 & 7.80 & 7.40 & 7.76 \\
\hline $\mathbf{T}_{2}$ & 8.20 & 7.50 & 7.10 & 7.60 & 8.00 & 7.33 & 7.20 & 7.51 \\
\hline $\mathbf{T}_{3}$ & 8.07 & 7.40 & 7.02 & 7.49 & 8.07 & 7.40 & 7.02 & 7.49 \\
\hline Mean & 8.19 & 7.66 & 7.17 & & 8.05 & 7.51 & 7.21 & \\
\hline $\mathrm{CD}_{0.05}$ & \multicolumn{3}{|c|}{$\begin{array}{l}\mathrm{T}(\text { Treatments })=0.28 \\
\mathrm{~S}(\text { Storage interval })=0.28 \\
\mathrm{TxS}=\mathrm{NS}\end{array}$} & $\mathrm{CD}_{0.05}$ & \multicolumn{3}{|c|}{$\begin{array}{l}\mathrm{T}(\text { Treatments })=0.14 \\
\mathrm{~S}(\text { Storage interval })=0.14 \\
\mathrm{TxS}=24\end{array}$} & \\
\hline
\end{tabular}

Table.8 Effect of different treatments and storage on taste and aroma scores of pumpkin-guava squash (on 9 point hedonic scale)

\begin{tabular}{|c|c|c|c|c|c|c|c|c|}
\hline \multirow[t]{3}{*}{ Treatment (T) } & \multicolumn{3}{|l|}{ Taste } & & \multicolumn{4}{|c|}{ Aroma } \\
\hline & \multicolumn{3}{|c|}{$\begin{array}{lll}\begin{array}{l}\text { Storage } \\
(\text { months })\end{array} & \text { interval } & (\mathbf{S})\end{array}$} & \multirow[b]{2}{*}{ Mean } & \multicolumn{4}{|c|}{$\begin{array}{l}\text { Storage interval }(\mathrm{S}) \\
\text { (months) }\end{array}$} \\
\hline & 0 & 3 & 6 & & 0 & 3 & 6 & Mean \\
\hline $\mathbf{T}_{1}$ & 8.40 & 7.73 & 7.23 & 7.79 & 8.23 & 7.81 & 7.40 & 7.81 \\
\hline $\mathbf{T}_{2}$ & 8.00 & 7.56 & 7.23 & 7.60 & 8.00 & 7.40 & 6.80 & 7.40 \\
\hline $\mathbf{T}_{3}$ & 8.07 & 7.44 & 7.02 & 7.51 & 8.07 & 7.35 & 7.02 & 7.48 \\
\hline Mean & 8.16 & 7.58 & 7.16 & & 8.10 & 7.52 & 7.07 & \\
\hline $\mathrm{CD}_{0.05}$ & \multicolumn{3}{|c|}{$\begin{array}{l}\mathrm{T}(\text { Treatments })=0.08 \\
\mathrm{~S}(\text { Storage interval })=0.08 \\
\mathrm{TxS}=0.15\end{array}$} & $\mathrm{CD}_{0.05}$ & \multicolumn{3}{|c|}{$\begin{array}{l}\mathrm{T}(\text { Treatments })=0.10 \\
\mathrm{~S}(\text { Storage interval })=0.10 \\
\mathrm{TxS}=0.17\end{array}$} & \\
\hline
\end{tabular}

Table.9 Effect of different treatments and storage on overall acceptability scores of pumpkinguava squash (on 9 point hedonic scale)

\begin{tabular}{|l|l|l|l|l|}
\hline \multirow{2}{*}{$\begin{array}{l}\text { Treatment } \\
(\mathbf{T})\end{array}$} & \multicolumn{4}{|l|}{ Storage interval (S) (months) } \\
\cline { 2 - 5 } & 0 & 3 & 6 & Mean \\
\hline $\mathbf{T}_{\mathbf{1}}$ & 8.33 & 7.30 & 6.80 & $\mathbf{7 . 4 8}$ \\
\hline $\mathbf{T}_{\mathbf{2}}$ & 8.00 & 7.20 & 6.74 & $\mathbf{7 . 3 1}$ \\
\hline $\mathbf{T}_{\mathbf{3}}$ & 8.07 & 7.35 & 6.50 & $\mathbf{7 . 3 0}$ \\
\hline Mean & $\mathbf{8 . 1 3}$ & $\mathbf{7 . 2 8}$ & $\mathbf{6 . 6 8}$ & \\
\hline $\mathrm{CD}_{0.05}$ & \multicolumn{4}{|l|}{$=0.09$} \\
& T (Treatments) & $=.09$ \\
& S (Storage interval) & $=0.16$ \\
\hline
\end{tabular}


Fig.1 Sensory evaluation (on 9 point hedonic scale) of pumpkin squash for Standardization of recipe

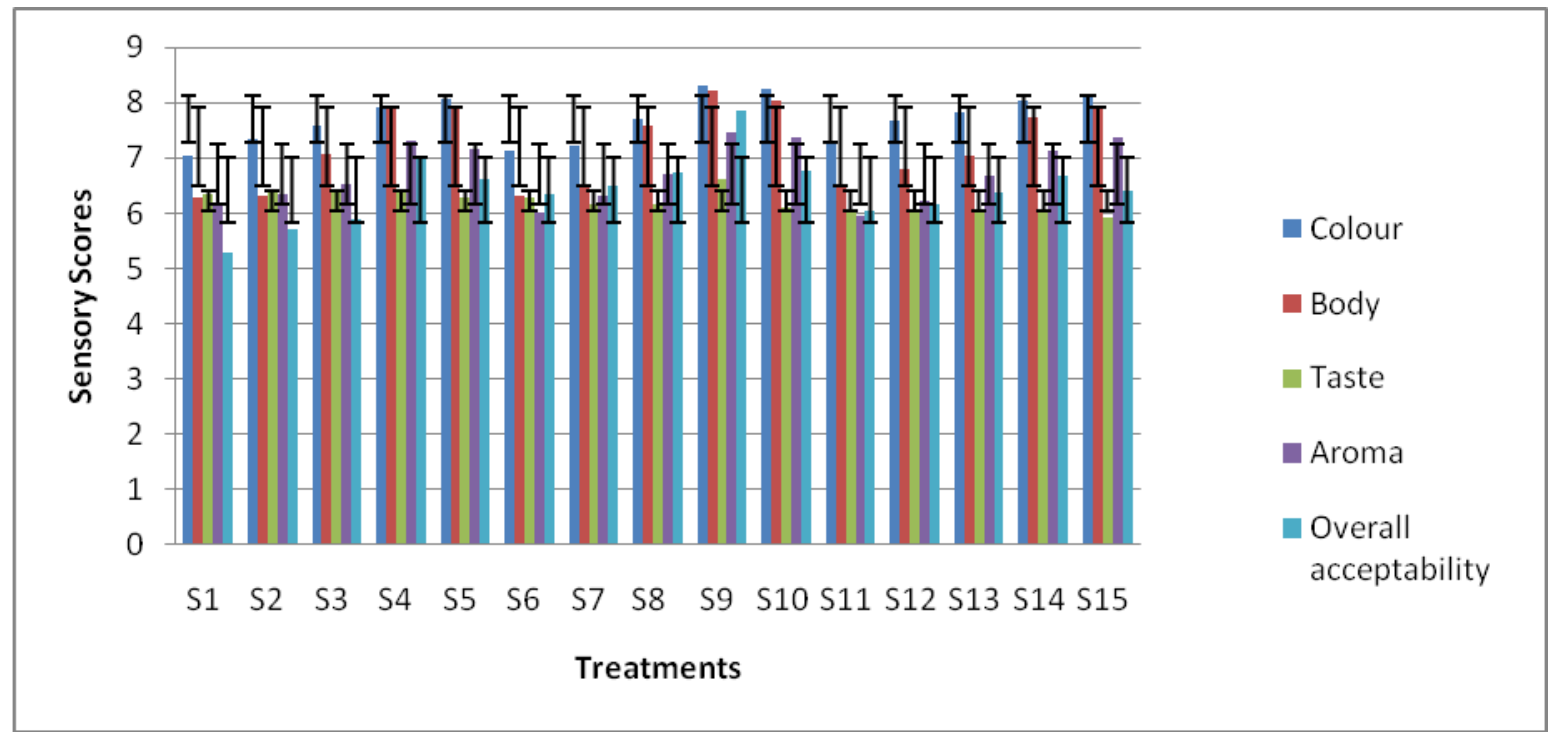

Fig.2 Sensory evaluation (on 9 point hedonic scale) of pumpkin-guava squash for Standardization of recipe

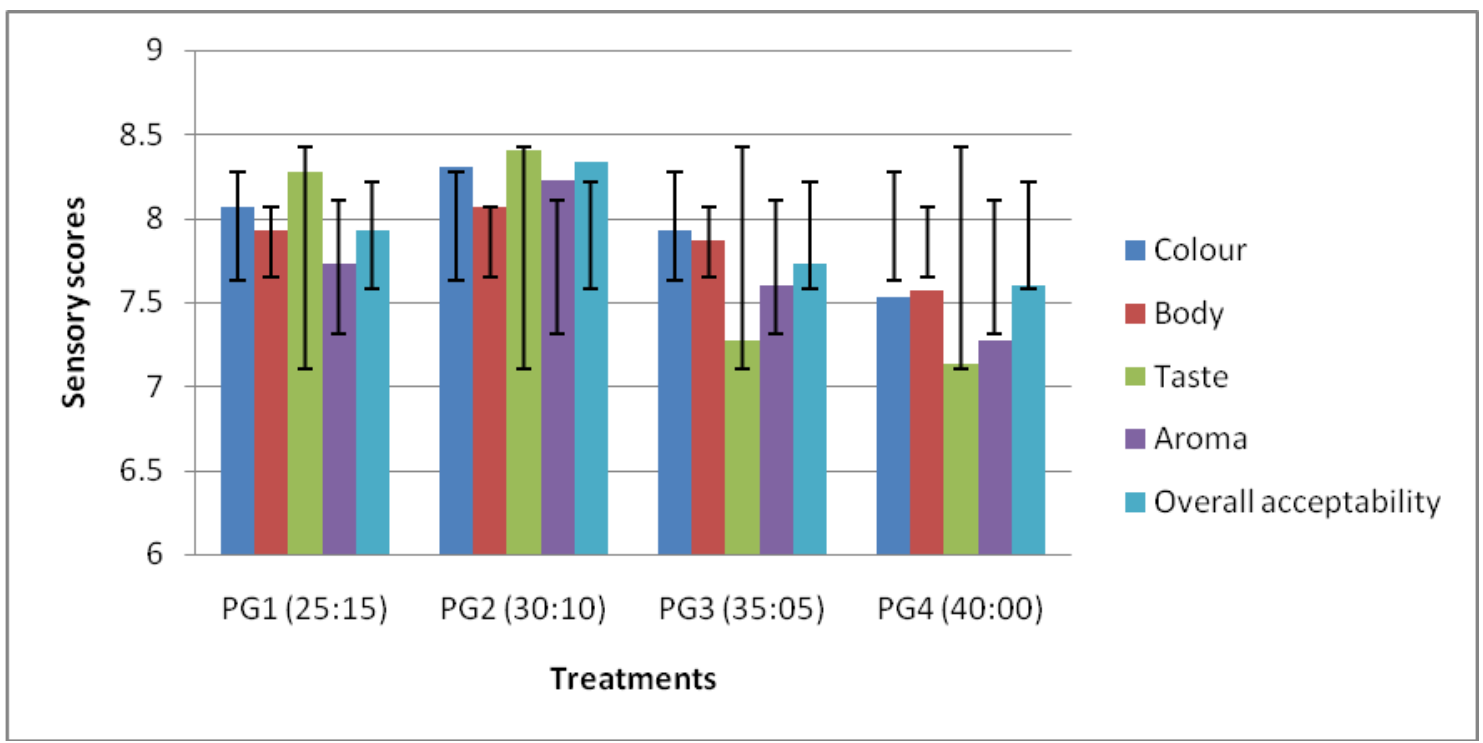

Increase in reducing sugars may be due to hydrolysis of non-reducing sugars like sucrose in to reducing sugars (glucose and fructose) during storage. Similar observations have been reported by Sethi (1992) for limeginger cocktail, Krishnaveni et al., (2001) for jack fruit squashes and Bhatia and Chawla (2004) for apple beverage. Sood et al., (2009) also noticed an increase in reducing sugars of mango squash.

\section{Ascorbic acid}

A gradual decrease in ascorbic acid of pumpkin-guava squash was observed during entire storage period under ambient condition. 
It can be clearly seen that among different treatments mean maximum value of 31.58 $\mathrm{mg} / 100 \mathrm{~g}$ was recorded in $\mathrm{T}_{2}$ (pumpkin-guava pulp+lime juice) and mean minimum of 22.19 $\mathrm{mg} / 100 \mathrm{~g}$ in $\mathrm{T}_{1}$ (pumpkin-guava pulp+citric acid). The ascorbic acid was found to decrease from 51.59 to $45.79 \mathrm{mg} / 100 \mathrm{~g}$ during the storage period of six months.

The decreasing trend in ascorbic acid during storage might be due to its breakdown in to dehydroascorbic acid or unstable nature of ascorbic acid by the action of heat, light and air or conversion to dehydroascorbic acid by its participation in browning (Sood et al., 2009). Krishnaveni et al., (2001) also revealed a decrease in ascorbic acid of jackfruit RTS beverage with the increase in storage intervals. The findings of the present studies are in agreement with the results reported by Jaiswal et al., (2008) in aonla squash, Diwedi and Pathak (2012) in mulberry squash and Syed et al., (2012) in sweet orange squash.

\section{$\beta$ - carotene}

An appraisal of data (Table 6) revealed that there was a decreasing trend in $\beta$-carotene content of pumpkin-guava squash during storage of six months. It was indicate that the mean value of $\beta$-carotene decreased from 0.51 to $0.22 \mathrm{mg} / 100 \mathrm{~g}$ during storage period of six months. A decrease in $\beta$-carotene might be due to the auto-oxidative degradation during processing and storage of food (Sharma et al., 2009) or due to oxidative breakdown, isomerization or enzymatic destruction of the pigments. Srivastava (1998) and Deka et al., (2005), respectively observed a slight decrease in total carotenoids of mango RTS and peach nectar during 6 months of storage.

A significant loss of $\beta$ - carotene has been noticed by Tiwari (2000) in guava-papaya beverage, Krishnaveni et al., (2001) in jack fruit beverage and Kenghe and Zambare (2009) in bael squash during storage.

Changes in sensory characteristics of pumpkin-guava squash during storage

The data from Table 7 to 9 reflect the sensory evaluation scores for pumpkin-guava squash. The storage period as well as treatments had significantly affected the average scores for colour, body, taste, aroma and overall acceptability of pumpkin squash. The highest scores were awarded to treatment $T_{1}$ (pumpkin-guava pulp+citric acid) for colour (7.92), body (7.76), taste (7.79), aroma (7.81) and overall acceptability (7.48). However, the average scores showed a decreasing trend in recipes of all the treatments for different attributes during storage but were found to be well above the acceptable limits.

The mean scores were found to decrease from 8.19 to 7.17 for colour, 8.05 to 7.21 for body, 8.16 to 7.16 for taste, 8.10 to 7.07 for aroma and 8.13 to 6.88 for overall acceptability during six months of storage. This decrease in sensory scores might be attributed to chemical changes or certain enzymatic and nonenzymatic reactions. A significant decreasing trend in sensory attributes has also been observed by Prasad and Mali (2000) in ber squash, Nidhi et al., (2008) in bael-guava beverage and Sood et al., (2009) in mango squash and Thakur (2014) in box myrtle squash during storage.

Pumpkin guava squash was highly acceptable and rich in nutritional components such as ascorbic acid and $\beta$-carotene. Pumpkin guava pulp in a ratio of 30 : 10 with $45^{\circ}$ Brix TSS was highly acceptable by the panelist (Table 2). During the storage study, it was observed that there was slight deterioration in the chemical composition of the squash as well as in sensory parameters but they were all in the acceptable limit. 


\section{Acknowledgement}

Authors are sincerely thankful to Department of Science and Technology (DST), New Delhi, India, through their Project "Development of low cost value added processed products from ripe pumpkin (Curcurbita moschata) and dissemination of technology to the farm women of Himachal Pradesh" for providing all kind of support to facilitate this experiment.

\section{References}

Ali, Z., Korekar, G., Mundra, S., Yadav, A. and Stobdan, T. 2011. Quality attributes of seabuckthorn squash during storage. Indian Journal of Horticulture, 68(4): 479-483.

Bhatia, A., and Chawla, P. 2004. Development of protein enriched apple beverage. Journal of Food Science and Technology, 41:174-177.

Bisognin, D. A., 2002. Origin and Evolution of Cultivated Cucurbits. Ciência Rural, 32(5): 715-723.

http://dx.doi.org/10.1590/S010384782002000400028

Caili, F. S., Huan, and Quanhong, L. 2006. A review on pharmacological activities and utilization technologies of pumpkin. Plant Foods for Human Nutrition, 61: 73-80.

Danilchenko, H., Paulauskiene, A., Dris, R. and Niskanen, R. 2000. Biochemical composition and composition and processability of pumpkin cultivars. Acta Horticulture, 510: 493-497.

Deka, B. C., Sethi, V. and Saikia, A. 2005. Changes in quality of mango pineapple spiced beverage during storage. Indian Journal of Horticulture, 62(1): 71-75.

Dhiman Anju, K., Sharma KD and Attri S. 2009. Functional constituent and processing of pumpkin-a review. Journal of Food Science and Technology 46(5): 411-417.

Dhiman, Anju, K., Negi, V., Attri, S. and Ramachandran, P. 2017. Optimization of instant halwa mix from dehydrated pumpkin and its stability during storage. International Journal of Agriculture Sciences, 9 (11): 4026-4030.

Diwedi, S. K., and Pathak, S. 2012. Development of protocol for preparation and preservation of squash beverages from mulberry (Morus nigra Linn.) fruits. Progressive Horticulture, 44(1): 19-21.

Hussain, I., Gilani, S. N., Khan, M. R., Khan, M. T. and Shakir, I. 2005. Varietal suitability and storage stability of mango squash. International Journal of Agriculture and Biology, 7(6): 10381039.

Jaiswal, R., Singh, G. and Singh, A. K. 2008. Evaluation of aonla (Emblica officinalis G.) cultivars for squash making. Progressive Agriculture 8(1): 29-31.

Kannan, S., and Thirumaran, A. S. 2002. Studies on storage behaviour of jamun products. Beverage and Food World, 29(3): 32-33.

Kannan, S. and Thirumaran, A. S. 2004. Studies on the storage life of jamum (Syzygium cuminii Rom.) fruit products. Journal Food Science Technology. 41(2):186188.

Kayshar, M. S., Rahman, A., Sultana, M. S., Fatema, K. and Kabir, M. F. 2014. Formulation, preparation and storage potentiality study of mixed squashes from papaya, banana and carrot in Bangladesh. Journal of Agriculture and Veterinary Science, 7(2): 47-51.

Kenghe, R. N., and Zambare, A. V. 2009. Effect of preservation on biochemical qualities of blended bael RTS beverages. Beverage and Food World pp.51-52

Krishnaveni, A., Manimegalai, G. and Saravana Kumar, R. 2001. Storage stability of jackfruit (Artocarpus heterophyllus) RTS beverage. Journal of Food Science and Technology, 38 (6): 601-602.

Kulkarni, A. S., and Joshi, D. C. 2013. Influence of Storage Temperature on Chemical and Microbial Quality of Carotene Rich Pumpkin Powder. International Journal of Agriculture, 
Environment \& Biotechnology, 7: 421426.

Kumar, R., Bawa, A. S., Kathiravan, T. and Nadanasabapathi, S. 2013. Thermal processing of mango nectar (Mangifera indica) and its effect on chemical, microbiological and sensory quality characteristics. International Journal of Advanced Research, 1(8): 261-273.

Malav, M., Gupta, R. and Nagar, T. 2014. Studies on biochemical composition of orange based blended RTS beverages. Bioscience Biotechnology Research Communication, 7(1): 78-83.

Nidhi, Gehlot, R., Singh, R. and Rana M. K. 2008. Change in chemical composition of ready-to-serve bael guava blended beverage during storage. Journal of Food Science and Technology 45(4): 378-380.

A. O. A. C., 2012. Official Methods of Analysis. 19th Edition, Association of Offical Analytical chemists. Washington DC.

Palinswamy, K. P., Muthukrishnan, C. R. and Shanmugavelu, K. G. 1984. Studies on the evaluation of certain mango verities of Tamil Nadu for pulp and squash. Beverage and Food World, 28(2): 5-9.

Pandey, S. J., Singh, A. K., Upadhyay, D. R., Mathura, R. 2003. Ascorbate and carotenoid content in an Indian collection of pumpkin (Cucurbita moschata Duch. ex Poir.). Cucurbit Genetics Cooperative Report, 26: 51-53.

Prasad, R.N., and Mali, P. C. 2000. Changes in physico-chemical characteristics of pomegranate squash during storage. Indian Journal of Horticulture, 57(1): 1820.

Ranganna, S., 2009. Handbook of analysis and quality control for fruit and vegetable products. Tata McGraw Hill, New Delhi.

Reddy, A. H., and Chikkasubbanna, V. 2008. Standardization of recipe and storage behaviour of lime blended amla squash.
The Asian Journal of Horticulture, 3(2): 203-207.

Relekar, P. P., Naik, A. G. and Padhiar, B. V. 2013. Effect of recipe on qualitative changes in sapota squash during storage. Indian Journal of Horticulture, 3(6): 22 27.

Sethi, V., 1992. Preparation and storage study of lime ginger cocktail at room and low temperature. Beverage and Food World, 19(12): 51-52.

Shahid, U., Hussain, S., Nadeem, M., Jabbar, M., Qureshi, T. M., Nasir, M. U., Zahra, M. S. and Rashid, F. 2015. Quality assessment of the mango-mandarin (kinnow) squash during storage. Open Access Journal, 3(2): 115-121.

Sharma, M., Gehlot, R., Singh, R. and Siddiqui, S. 2009. Studies on physico-chemical composition fresh guava and jamun fruits. Haryana Journal of Horticultural Sciences, 38(1): 68-69.

Sood, S., Minhas, S., Kalia, M. and Katoch, S. 2009. Storage study of mango squash by using cheese whey and soy whey. Beverage and Food World 36(4): 44-46.

Srivastava, J. S., 1998. Comparative study of RTS drinks prepared from Dashehari and Banganpalli mangoes. Indian Food Packer, 52(2): 38-40.

Syed, H. M., Ghatge, P. U., Machewad, G. and Pawar, S. 2012. Studies on preparation of squash from sweet orange. Open Access Scientific Reports, 1(6): 185-187.

Thakur, A., 2014. Development of value added products from box myrtle (Myrica nagi). M.Sc Thesis, Dr Y S Parmar university of Horticulture and Forestry, Nauni, Solan (HP).

Tiwari, R. B., 2000. Studies on blending of guava and papaya pulp for RTS beverages. Indian Food Packer 54: 6872.

\section{How to cite this article:}

Anju K. Dhiman, G. Nagendra Babu, Attri Surekha and Ramchandran Preethi. 2017. Development and Standardization of Ripe Pumpkin Based Squash and its Stability during Storage. Int.J.Curr.Microbiol.App.Sci. 6(10): 821-831. doi: https://doi.org/10.20546/ijcmas.2017.610.098 